\title{
Perangkat Pembelajaran Berbasis Proyek Mata Diklat Instalasi LAN Jurusan Teknik Komputer dan Jaringan
}

\author{
Ilham Tri Maulana ${ }^{1}$, Restyaliza Dhini Hary ${ }^{1}$ \\ ${ }^{1}$ Sistem Informasi-STMIK Indonesia Padang
}

\begin{tabular}{l}
\hline \hline INFO ARTIKEL \\
\hline Riwayat Artikel: \\
Diterima: $12-12-2018$ \\
Disetujui: $16-02-2019$ \\
\hline
\end{tabular}

\section{Kata kunci:}

project based learning; learning outcomes; pembelajaran berbasis proyek; hasil belajar

\author{
Alamat Korespondensi: \\ Ilham Tri Maulana \\ Sistem Informasi \\ STMIK Indonesia Padang \\ Jalan Khatib Sulaiman Dalam No. 1 Kel. Padang Utara, Padang, Sumatera Barat \\ E-mail: ilhamtm@stmikindonesia.ac.id
}

\section{ABSTRAK}

Abstract: This research was aimed to produce a valid and effective project-based learning model. The method used in this research is the Research and Development model of the development of Instructional Development Institute. The result of this research indicate that the validity of project based learning tools on aspects of the content, presentation, and format valid. The effectiveness of the test, an project based learning tools considered very effective as many as 25 of the 29 student reached value of $\geq 75$.

\begin{abstract}
Abstrak: Penelitian ini bertujuan untuk menghasilkan sebuah model pembelajaran berbasis proyek yang valid dan efektif. Metode Penelitian yang digunakan dalam penelitian ini adalah Research and Development menggunakan model pengembangan Instructional Development Institute. Hasil dari peneltian ini menunjukkan bahwa validitas perangkat pembelajaran berbasis proyek berdasarkan aspek isi, penyajian dan format dikategorikan valid. Pada uji keefektifan, pembelajaran berbasis proyek dinilai sangat efektif karena sebanyak 25 dari 29 mahasiswa berhasil mencapai nilai $\geq 75$.
\end{abstract}

Sistem pembelajaran dengan model, perangkat metode dan strategi didalamnya merupakan bagian penting untuk menghasilkan ketercapaian lulusan yang berdaya saing tinggi (Firdian \& Maulana, 2018). Sistem pembelajaran adalah sistem mampu memberikan pengalaman belajar secara bermakna kepada mahasiswa untuk membuka keunikan potensi dirinya dalam memaksimalkan knowledge, skills, dan attitudes (Maulana, 2017). Ketercapaian tujuan pembelajaran dalam proses pembelajaran ditandai dengan adanya perubahan tingkah laku. Perubahan tingkah laku tersebut baik menyangkut perubahan yang bersifat pengetahuan (kognitif), keterampilan (psikomotor) maupun yang menyangkut nilai dan sikap (afektif). Terdapat dua faktor yang memengaruhi tercapainya tujuan pembelajaran. Faktor utama yang memengaruhi hasil belajar, yaitu faktor internal dan eksternal. Faktor internal, mencakup faktor jasmaniah, intelengensi, motivasi, perhatian, minat, bakat dan kesiapan. Faktor eksternal terdiri dari faktor keluarga, masyarakat, kurikulum, dan model pembelajaran. Model pembelajaran yang diberikan kepada siswa sebaiknnya bervariasi supaya siswa mudah menerima materi pelajaran dan menguasainya sehingga siswa lebih termotivasi dan maju dalam belajar.

Model pembelajaran berfungsi pula sebagai pedoman bagi para perancang pembelajaran dan para guru dalam merencanakan aktivitas belajar mengajar. Konteks pembelajaran bermakna, guru memegang posisi strategis untuk menciptakan suasana belajar aktif dan menyenangkan melalui penerapan model pembelajaran (Nuramalina, Basuki, \& Suyono, 2019). Dalam penerapannya, guru diberikan kebebasan dalam merencanakan, melaksanakan dan menilai kurikulum serta hasil belajar siswa pada saat menyampaikan kompetensi inti dan kompetensi dasar sebagai cermin penguasaan dan pemahaman terhadap mata diklat yang dipelajari. Guru salah satu faktor penting untuk mewujudkan proses dan tujuan dari proses pembelajaran itu sendiri, terutama dalam menentukan model dan strategi pembelajaran yang dapat mengarahkan siswa belajar dengan lebih bermakna dan menyenangkan sehingga dapat menjadikan siswa mampu berpartisi aktif, mandiri, meningkatkan keterampilan, dan berkreasi atau mengekspresikan ide-ide yang ada dalam pikirannya.

Salah satu mata diklat yang diajarkan di Sekolah Menengah Kejuruan, khususnya paket keahlian Teknik Komputer Jaringan adalah Instalasi Jaringan LAN Instalasi Jaringan merupakan salah satu mata pelajaran kelompok C2 (Produktif). Sebagaimana yang ditetapkan Silabus Kurikulum Tingkat Satuan Pendidikan mata pelajaran produktif Teknik Komputer Jaringan kelas XI Kompetensi Dasar mata pelajaran Instalasi Jaringan adalah Membuat desain awal jaringan LAN. Indikator adalah sebagai berikut dapat dilihat pada tabel 1. 
Tabel 1. Kompetensi Dasar Instalasi Jaringan LAN

\begin{tabular}{|c|c|c|c|}
\hline No & Kompetensi Dasar & Indikator & Materi Pembelajaran \\
\hline 1 & $\begin{array}{l}\text { Membuat Desain Awal } \\
\text { Jaringan LAN }\end{array}$ & $\begin{array}{ll}\text { a. Pengertian LAN, WAN, } \\
\text { MAN, Internet, Bandwidth } \\
\text { b. Jenis- Jenis topologi dan } \\
\text { arsitektur jaringan komputer } \\
\text { c. Protokol pada jaringan } \\
\text { komputer } \\
\text { d. Prinsip dasar pengalamatan } \\
\text { IP Address } \\
\text { e. Pengertian dan cara Kerja } \\
\text { DNS Dan DHCP }\end{array}$ & 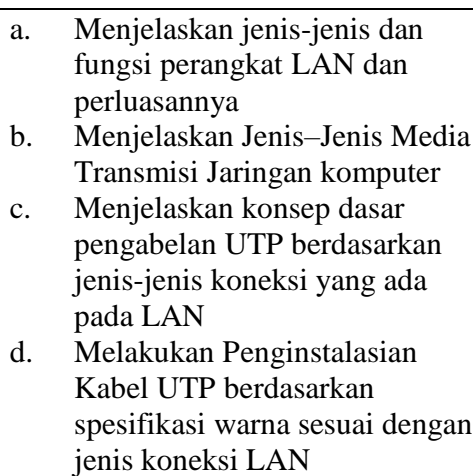 \\
\hline
\end{tabular}

\section{Sumber: Guru Mata Diklat Instalasi LAN Tahun 2017}

Dalam pembelajaran Instalasi Jaringan LAN siswa dituntut untuk aktif dan dapat menguasai materi sebelumnya yang mereka pelajari karena materi yang disajikan dalam pembelajaran Instalasi Jaringan LAN saling berhubungan dan saling melengkapi antara satu materi dengan materi lainnya sehingga dengan model pembelajaran yang dikembangkan dapat mewujudkan siswa yang mampu mandiri, berkreasi dengan ide-ide atau ilmu yang dimilikinya, salah satunya dengan mengembangkan model pembelajaran. Berdasarkan pengamatan dan observasi yang telah dilakukan di jurusan Teknik Komputer Jaringan (TKJ) di SMK Muhammadiyah 1 Padang, Kecenderungan proses pembelajaran selama ini guru mata diklat Instalasi Jaringan LAN menggunakan model pembelajaran langsung (ceramah), sedangkan mata pelajaran ini merupakan salah satu mata pelajaran produktif. Oleh karena itu, guru harus mampu menerapkan model pembelajaran yang cocok.

Dalam pelaksanaan pembelajaran guru belum mempunyai inisiatif untuk mengembangkan sebuah model pembelajaran yang lainnya sesuai dengan konten atau materi pembelajaran sehingga siswa hanya diberikan pelajaran sebatas bahan yang ada dibuku teks, kondisi ini membuat siswa menjadi jenuh dan pembelajaran bersifat monoton, hal ini berakibat pada kegiatan pembelajaran menjadi kurang menarik, tidak optimal bagi siswa dan kurang efektifnya pembelajaran, serta bagaimana menghubungkan antara apa yang dipelajari dengan kehidupan nyata dan bagaimana memanfaatkan pengetahuan yang diperoleh untuk menunjang kehidupannya. Penerapan pembelajaran yang aktif menuntut kemampuan guru merancang dan mengembangkan perangkat pembelajaran berupa model yang dapat membantu siswa maupun guru dalam proses pembelajaran (Maulana, 2017). Berdasarkan data hasil belajar dilihat dari data dibawah, persentase kelulusan siswa pada mata diklat Instalasi Jaringan LAN $53,33 \%$ atau 16 orang siswa yang melewati batas Kriteria Ketuntasan Minimal pada mata diklat Instalasi Jaringan LAN kelas XI semester ganjil Tahun Ajaran 2017/2018 yang dapat dilihat pada tabel 2.

Tabel 2. Persentase Hasil Belajar Mata Diklat Instalasi Jaringan LAN Siswa Jurusan TKJ Semester Ganjil Kelas XI Tahun Pelajaran 2017/2018

\begin{tabular}{|c|c|c|c|c|c|c|}
\hline \multirow{3}{*}{ No. } & \multirow{3}{*}{ Kelas } & \multirow{3}{*}{ Jumlah } & \multicolumn{4}{|c|}{ Ketuntasan } \\
\hline & & & \multicolumn{2}{|c|}{ Nilai $<75$} & \multicolumn{2}{|c|}{ Nilai $>75$} \\
\hline & & & Jumlah & Persentase \% & Jumlah & Persentase \% \\
\hline 1. & Kelas X TKJ 1 A & 15 & 3 & $20 \%$ & 12 & $80 \%$ \\
\hline 2. & Kelas X TKJ 1 B & 16 & 12 & $75 \%$ & 4 & $25 \%$ \\
\hline & Jumlah & & 15 & $46,67 \%$ & 16 & $53,33 \%$ \\
\hline
\end{tabular}

Sumber: Guru Mata Diklat Instalasi LAN Tahun 2017

Dari pengamatan penelitian dan data ketuntasan hasil belajar sebenarnya banyak faktor yang membuat hasil belajar siswa kurang memenuhi standar Kriteria Ketuntasan Minimal salah satunya penyebabnya adalah penerapan pembelajaran yang telah ada. Terutama untuk mata diklat Instalasi Jaringan LAN yang mendominasi pembelajaran praktek, proses pembelajaran terfokus pada tingkatan kemampuan siswa untuk saat belajar saja, membuat siswa menjadi jenuh dan bersifat monoton. Agar berhasil, guru diharapkan untuk menegosiasikan tujuan dan standar tugas, untuk bertindak secara strategis sambil memantau, untuk merevisi proses dan hasil, untuk menggunakan yang sesuai alat teknologi, dan untuk secara produktif menghadapi tantangan yang mereka hadapi (Splichal, Oshima, \& Oshima, 2018). Oleh karena itu, diperlukan model pembelajaran yang dapat merangsang tumbuhnya pemikiran kritis, kreativitas, dan keterampilan pemecahan masalah bagi siswa sekolah kejuruan (Samani, Putra, Rahmadian, \& Rohman, 2019). Penerapan perangkat pembelajaran berbasis proyek dapat membantu siswa mengeksplorasi diri, 
mandiri, aktif, inovatif, dan kreatif dalam proses pembelajaran. Pembelajaran berbasis proyek adalah salah satu metode pembelajaran aktif di mana beberapa masalah dan insiden ditemui dalam kehidupan nyata diselidiki dan hasilnya dinyatakan dalam presentasi lisan atau laporan tertulis (Solmaz Aydin, Tazegül Demir Atalay, 2018). Pembelajaran berbasis proyek adalah pendekatan yang mencakup pembelajaran kontekstual dan bermakna (Nasruloh, 2013).

Pembelajaran berbasis proyek adalah model pembelajaran didasarkan pada kenyamanan peserta didik pada isu dunia nyata dan masalah bahwa mereka menemukan dengan penuh arti, menentukan bagaimana untuk menunjukkan kepada mereka, kemudian beraksi dalam kolaborasi untuk menciptakan solusi permasalahan (Pandangwati, Ulfa, \& Toenlioe, 2018). Pembelajaran berbasis proyek merupakan kegiatan pembelajaran yang membuat siswa bekerja di dalam tim, menemukan keterampilan merencanakan, mengorganisasi, bernegosiasi, bertanggung jawab terhadap tugas yang telah ditetapkan, belajar dan mengumpulkan informasi dan mengomunikasikannya secara ilmiah dapat meningkatkan kemampuan memecahkan masalah, meningkatkan kreativitas, inovasi, kerjasama tim, dan kemampuan berkomunikasi dengan baik (Timutiasari, Al-Muhdhar, \& Suhadi, 2016).

Perlu ditekankan pembelajaran berbasis proyek; mengembangkan dan memperkaya pembelajaran keterampilan siswa, memberikan pembelajaran seumur hidup, membuat mereka mengadopsi kebiasaan belajar ilmiah, memungkinkan siswa untuk berpartisipasi dalam kegiatan pembelajaran berdasarkan kerja tim dan kolaborasi, memungkinkan penggunaan yang berbeda dimensi kecerdasan, memberikan informasi yang signifikan kepada keluarga, guru, administrasi sekolah mengenai kinerja siswa, mengembangkan keterampilan pemecahan masalah dan keterampilan belajar berbasis masalah. Selain itu, pembelajaran berbasis proyek memberikan siswa berbagai keterampilan. Ini melibatkan keterampilan yang menopang kehidupan, keterampilan menggunakan teknologi, keterampilan proses kognitif, keterampilan mengendalikan diri, sikap, kecenderungan, dan kepercayaan (Solmaz Aydin, Tazegül Demir Atalay, 2018). Meskipun definisi bervariasi dalam spesifik, pembelajaran berbasis proyek biasanya dianggap sebagai pendekatan untuk mengajar di mana siswa menanggapi pertanyaan atau tantangan dunia nyata melalui proses penyelidikan yang diperpanjang. PBL mengatur pembelajaran di sekitar proyek dan melibatkan siswa (Chiang \& Lee, 2016).

Penelitian ini bertujuan untuk menambah variasi model pembelajaran di dalam pembelajaran dan mengetahui validitas, efektifitas model pembelajaran berbasis proyek yang dikembangkan. Hasil penelitian ini diharapakan dapat bermanfaat bagi dunia pendidikan, baik secara teoritis maupun praktis. Secara teoritis tersedianya referensi penggunaan model pembelajaran berbasis proyek. Secara praktis, penelitian ini diharapakan dapat bermanfaat untuk memberikan alternatif model pembelajaran yang dinamis bagi siswa, guru, dan sekolah serta menjadi upaya untuk meningkatkan aktivitas, minat, dan pemahaman siswa sehingga hasil belajar siswa meningkat, serta menambah pengetahuan dan keterampilan guru dalam pengembangan model pembelajaran. Selanjutnya, bagi sekolah dapat membantu dalam inovasi model pembelajaran yang berbasis proyek.

\section{METODE}

Berdasarkan masalah dalam penelitian ini, maka jenis penelitian yang akan digunakan penelitian ini adalah penelitian pengembangan atau development research. Model pengembangan yang digunakan adalah model Instructional Development Institute (IDI). IDI menerapkan prinsip-prinsip pendekatan sistem yang meliputi tiga tahapan, yaitu penemuan (define) atau analisis kebutuhan, pengembangan (develop), dan evaluasi (evaluate) (Firdian \& Maulana, 2018).

Tahap pertama yaitu tahap peemuan (define) yang berisikan langkah-langkah analisis latar belakang dan identifikasi masalah. Tahap kedua adalah tahap pengembangan (develop) yang berisikan penyusunan bentuk awal (prototype) model dan validasi model. Tahap ketiga yaitu tahap evaluasi/penilaian (evaluate) yang berisikan langkah-langkah uji coba dan analisis hasil uji coba.

Peneliti memilih model IDI karena peneliti melihat bahwa model dengan pendekatan sistem ini sesuai dengan masalah yang menjadi latar belakang dalam penelitian ini. Dengan adanya analisis kebutuhan (needs analysis), melihat karakteristik siswa, guru dan kondisi fasilitas sekolah yang ada, maka peneliti berharap dengan dikembangkan model pembelajaran berbasis proyek yang valid dan efektif dapat meningkatkan hasil belajar mata diklat Instalasi LAN.

Jenis data yang digunakan dalam pengembangan model pembelajaran berbasis proyek ini adalah data primer, artinya data yang langsung didapatkan dari subjek penelitian yakni yang sudah divalidasi oleh pakar/ahli dan praktisi, aspek yang divalidasi terdiri dari isi/konten, format, Penyajian perangkat pembelajaran berbasis proyek dalam bentuk buku siswa dan guru yang melaksanakan pembelajaran dengan pembelajaran berbasis proyek. Data yang dimaksud disini adalah hasil penelitian kualitatif yang diberikan ahli/guru dan siswa melalui angket yang diberikan hasilnya dianalisis dengan menggunakan rumus statistik

Instrumen penelitian yang dikembangkan untuk mengumpulkan data dalam penelitian ini sebagai berikut. Pertama, lembaran validasi dimaksud untuk mengetahui kevalidan perangkat pembelajaran berbasis proyek dalam bentuk buku guru dan siswa oleh pakar/validator sehingga sudah dinyatakan valid. Kedua, efektivitas pembelajaran berbasis proyek efektif dalam meningkatkan hasil belajar siswa sebelum dengan setelah menggunakan pembelajaran berbasis proyek, setelah melalui uji coba. 


\section{HASIL \\ Data Uji Validitas}

Validitas berkaitan dengan keakuratan perangkat yang dikembangkan berbasis proyek yang dikembangkan. Data validitas diperoleh melalui angket yang diisi oleh tiga orang ahli yaitu aspek konten/isi, aspek format, dan aspek penyajian. Dari isian angket dapat dilihat kevalidan model pembelajaran berbasis proyek. Hasil penilaian terhadap kevalidan model pembelajaran berbasis proyek dapat dilihat pada tabel 3 .

Tabel 3. Hasil Uji Validitas

\begin{tabular}{ccccc}
\hline No & Aspek Validasi & Jumlah Skor & Nilai Validitas (\%) & Kriteria \\
\hline 1 & Content/Isi & 55 & 91.67 & Sangat Valid \\
2 & Penyajian & 26 & 86.67 & Valid \\
3 & Format & 31 & 88.57 & Valid \\
& Jumlah Skor & $\mathbf{1 1 2}$ & $\mathbf{8 8 , 9 6}$ & Valid \\
\hline
\end{tabular}

Berdasarkan tabel 3 di atas ditemukan bahwa hasil uji validasi perangkat pembelajaran berbasis proyek dari tiga orang validator menyatakan bahwa perangkat pembelajaran yang dikembangkan berada pada kategori tingkat validitas valid. Berdasarkan pada tabel 3 tersebut terlihat bahwa perangkat pembelajaran sudah memenuhi aspek isi dengan nilai validitas $91.67 \%$ (Sangat Valid). Aspek penyajian dengan nilai validitas $86.67 \%$ (Valid) dan aspek format dengan nilai validitas $88.57 \%$ (Valid). Ketiga aspek tersebut apabila dijumlahkan skor nilai validitas yang diperoleh dari masing-masing validator maka didapatkan nilai validitas $88.96 \%$. Nilai yang didapatkan ini berada pada kategori tingkat validitas valid.

\section{Data Uji Efektivitas}

Data hasil belajar diambil bertujuan untuk melihat sejauh mana prestasi siswa dalam mengikuti proses pembelajaran dengan menggunakan perangkat pembelajaran berbasis proyek pada mata diklat Instalasi jaringan LAN. Data hasil belajar diambil setelah dilakukan 4 x pertemuan dalam pembelajaran, dengan bentuk soal pilihan ganda sebanyak 20 soal. Dari data diperoleh 25 orang siswa yang sudah tuntas $(86.18 \%)$ dan siswa yang belum tuntas adalah sebanyak 4 orang (13.82\%). Meningkat sebanyak 9 $(32.87 \%)$ orang dari nilai hasil belajar mata diklat instalasi LAN semester ganjil kelas XI tahun pelajaran 2017-2018 yang lulus hanya 16 orang $(53.33 \%)$ untuk lebih jelasnya dapat dilihat pada tabel 4.

Tabel 4. Hasil Uji Efektivitas

\begin{tabular}{ccccccc}
\hline \multirow{2}{*}{ No. } & \multirow{2}{*}{ Kelas } & Jumlah & \multicolumn{2}{c}{ Nilai $<\mathbf{7 5}$} & \multicolumn{2}{c}{ Netuntai $>\mathbf{7 5}$} \\
\cline { 3 - 7 } & & & Jumlah & Persentase \% & Jumlah & Persentase \% \\
\hline 1 & Kelas X TKJ 1 A & 15 & 2 & $13.34 \%$ & 13 & $86.66 \%$ \\
2 & Kelas X TKJ 1 B & 14 & 2 & $14.29 \%$ & 12 & $85.71 \%$ \\
& Jumlah & & $\mathbf{4}$ & $\mathbf{1 3 . 8 2 \%}$ & $\mathbf{2 5}$ & $\mathbf{8 6 . 1 8 \%}$ \\
\hline
\end{tabular}

\section{PEMBAHASAN}

Perangkat Pembelajaran berbasis proyek dirancang bertujuan untuk meningkatkan aktivitas, minat, dan pemahaman siswa, dimana siswa diberikan arahan untuk dapat memahami dan melaksanakan secara mandiri proses pembelajaran yang terdapat di dalam perangkat pembelajaran berbasis proyek sehingga meningkatkan hasil belajar siswa kelas XI pada mata diklat Instalasi LAN.

Perangkat pembelajaran berbasis proyek yang dikembangkan sesuai dengan materi pada mata diklat Instalasi Jaringan LAN yang diajarkan kepada siswa kelas XI semester II TKJ di SMK Muhammadiyah 1 Padang. Pengembangan model pembelajaran berbasis proyek ini dilakukan dengan model pengembangan IDI, dimana tahap pengembangan perangkat pembelajaran berbasis proyek ini sebagai berikut.

\section{Validitas Perangkat Pembelajaran Berbasis Proyek}

Berdasarkan hasil validasi secara keseluruhan oleb tiga orang validator mengenai aspek konten/isi, penyajian dan format terhadap perangkat pembelajaran dapat diketahui bahwa perangkat pembelajaran sudah memenuhi aspek isi dan minat dengan nilai validitas $91.67 \%$, aspek penyajian dengan nilai validitas $86.67 \%$, dan aspek format dari validator maka didapatkan nilai validitas $88.57 \%$. Nilai yang didapatkan ini berada pada kategori tingkat validitas valid. Valid artinya sudah memberikan informasi yang akurat tentang bahan ajar yang dikembangkan. 


\section{Efektivitas Perangkat Pembelajaran Berbasis Proyek}

Keefektifan perangkat pembelajaran berbasis proyek pada penelitian ini dilihat dari kemampuan model pembelajaran untuk mengaktifkan siswa dalam belajar dan memudahkan dalam memahami materi pembelajaran. Penggunaan bahan ajar akan sangat membantu keefektifan proses pembelajaran dan penyampaian pesan saat itu. Selain meningkatkan aktivitas bahan ajar juga dapat membantu siswa meningkatkan pemahaman. Pada penilaian ini, keefektifan bahan ajar ditinjau dari segi hasil belajar siswa.

Hasil belajar dilihat untuk melihat keefektifan penggunaan perangkat pembelajaran berbasis proyek dilakukan dengan mengadakan postest setelah siswa melakukan pembelajaran dengan menggunakan perangkat pembelajaran berbasis proyek dengan jumlah siswa 29 orang. Data hasil belajar diambil setelah dilakukan 4 x pertemuan dalam pembelajaran, dengan bentuk soal pilihan ganda sebanyak 20 soal. Dari data diperoleh 25 orang siswa yang sudah tuntas (86.18\%) dan siswa yang belum tuntas adalah sebanyak 4 orang (13.82\%). Meningkat sebanyak 9 (32.87\%) orang dari nilai hasil belajar mata diklat instalasi LAN semester ganjil kelas XI tahun pelajaran 2017-2018 yang lulus hanya 16 orang (53.33\%).

Dari hasil belajar ini dapat disimpulkan bahwa perangkat pembelajaran yang dikembangkan peneliti efektif digunakan untuk meningkatkan hasil belajar siswa. Keefektifan mengacu pada tingkat pengalaman dan hasil intervensi yang dimaksud. Keefektifan buku ajar berbasis produk yang dikembangkan dapat dilihat dari hasil belajar siswa yang dilibatkan langsung dalam proses pembelajaran.

\section{SIMPULAN}

Pada penelitian pengembangan ini menghasilkan sebuah referensi penggunaan perangkat pembelajaran berbasis proyek dalam bentuk buku guru dan siswa yang sudah divalidasi oleh validator, perangkat pembelajaran berbasis proyek yang valid dan efektif pada mata diklat Instalasi jaringan LAN jurusan teknik komputer dan jaringan kelas XI semester II di SMK Muhammadiyah I Padang. Perangkat pembelajaran berbasis proyek pada mata diklat instalasi jaringan LAN yang dikembangkan ini didasarkan pada standar kompetensi. Perangkat pembelajaran berbasis proyek ini terdiri dari satu kompetensi dasar pembelajaran yang saling berkaitan yang mengarahkan siswa dalam desain awal jaringan LAN.

Berdasarkan keterbatasan pengembangan yang diperoleh saat melakukan uji coba di lapangan, dapat disarankan beberapa hal sebagai berikut. Pertama, bagi peneliti selanjutnya, perangkat pembelajaran berbasis proyek pada mata diklat Instalasi jaringan LAN dapat diujicobakan pada jumlah subjek uji coba yang lebih besar sehingga keterpakaian perangkat pembelajaran berbasis proyek ini jauh lebih luas. Kedua, bagi guru, perangkat pembelajaran berbasis proyek yang dikembangkan ini Guru diharapkan memiliki wawasan yang luas dalam bidang desain awal jaringan LAN. Sehingga dalam pembelajaran praktik guru dapat mengarahkan peserta didik untuk menghasilkan produk yang nantinya dapat disesuaikan dengan perkembangan zaman dan teknologi. Ketiga, bagi siswa yang agar dapat lebih menggali potensi diri sehingga mampu mengembangkan keterampilan dan keahlian.

\section{Ucapan Terima Kasih}

Ucapan terima kasih kepada Kementerian Riset, Teknologi, dan Pendidikan Tinggi melalui hibah bersaing nasional skema penelitian dosen pemula (PDP) yang telah membiayai penelitian ini dengan nomor kontrak 114/SP2H/LT/DRPM/2018. Juga ucapan terima kasih untuk STMIK Indonesia Padang yang telah mendukung pelaksanaan penelitian ini.

\section{DAFTAR RUJUKAN}

Aydin, S., Atalay, T. D., \& Goksu, V. (2018). Project-Based Learning Practices with Secondary School Students 1. International Online Journal of Educational Sciences, 10((3), 230-242.

Chiang, C. L., \& Lee, H. (2016). The Effect of Project-Based Learning on Learning Motivation and Problem-Solving Ability of Vocational High School Students. International Journal of Information and Education Technology, 6(9), 709-712. DOI: 10.7763/IJIET.2016.V6.779

Firdian, F., \& Maulana, I. T. (2018). Pengembangan Media Pembelajaran Multimedia Interaktif pada Matakuliah Aplikasi Software. Jurnal Pendidikan: Teori, Penelitian, dan Pengembangan, 3(6), 822-828.

Maulana, I. T. (2017). Pengembangan Media Pembelajaran CD Interaktif untuk Mata Diklat Jaringan Dasar. Indonesian Journal of Computer Science, 6(1), 96-108.

Maulana, I. T., \& Firdian, F. (2017). Perancangan Media Pembelajaran Multimedia Interaktif untuk Matakuliah Aplikasi Software. Jurnal Sains dan Informatika, 3(12), 89-96. http://doi.org/10.22216/jsi.v3i2.2350

Nasruloh, M. I. (2013). Teacher-Student Interaction In A Project-Based Learning Classroom. Journal of English and Education, l(1), 142-153.

Nuramalina, N., \& Basuki, I. A., \& Suyono. (2019). Pengaruh Model Kolaboratif Berbasis Masalah terhadap Kepuasan Belajar Siswa Sekolah Dasar. Jurnal Pendidikan: Teori, Penelitian, dan Pengembangan, 4(1), 29-35.

Pandangwati, T., Ulfa, S., \& Toenlioe, A. J. E. (2018). Pembelajaran Berbasis Proyek Mata Pelajaran Prakarya dan Kewirausahaan dengan Rangkaian LEAD ( Listen, Explore, Analyze, and Do) untuk Menumbuhkan Adversity Quotient Berbantuan Mobile Learning Schoology. Jurnal Pendidikan : Teori, Penelitian, dan Pengembangan, 3(7), 873-877. 
Samani, M., Putra, B. A. W., Rahmadian, R., \& Rohman, J. N. (2019). Learning Strategy to Develop Critical Thingking, Creativity, and Problem-Solving Skills. Jurnal Pendidikan Teknologi dan Kejuruan, 25(1), 36-42. https://doi.org/10.21831/jptk.v25i1.22574

Splichal, J. M., Oshima, J., \& Oshima, R. (2018). Regulation of Collaboration in Project-Based Learning Mediated by CSCL Scripting Reflection. Computers \& Education: An International Journal, 125, 132-145. https://doi.org/10.1016/j.compedu.2018.06.003

Timutiasari, B., Al-Muhdhar, M. H. I., \& Suhadi. (2016). Pembelajaran Berbasis Proyek Berbantuan Modul Program KRPL untuk dan Keterampilan Proses Sains Siswa SD Islam Moh. Hatta Malang. Jurnal Pendidikan: Teori, Penelitian dan Pengembangan, 1(6), 1185-1190. 